Macy, I. G., and Kelly, H. J. (1961). Human milk and cow's milk in infant nutrition. In Milk: The Mammary Gland and its Secretion, Vol. II, p. 265 . Ed. by S. K. Kon and A. T. Cowie. Academic Press, New York.

Shukla, A., Forsyth, H. A., Anderson, C. M., and Marwah, S. M. (1972). Infantile overnutrition in the first year of life. A field study in Dudley, Worcestershire. British Medical fournal, 4, 507.

Taitz, L. S. (1971). Infantile overnutrition among artificially fed infants in the Sheffield region. British Medical fournal, 1, 315.

Taitz, L. S., and Byers, H. D. (1972). High calorie/osmolar feeding and hypertonic dehydration. Archives of Disease in Childhood, 47, 257.

D. P. DAvies ${ }^{\star}$ and R. SAUNDERS

Department of Child Health, University Hospital of Wales, Cardiff, and Department of Biochemistry, Llandough Hospital.

*Correspondence to Dr. D. P. Davies, Department of Child Health, University Hospital of Wales, Heath Park, Cardiff CF4 4XN.

\section{Plasma growth hormone response to exercise as diagnostic aid}

The development and application of an exercise test to screen subjects for possible growth hormone (GH) deficiency has recently been described (Buckler, 1972). This depended on estimating the plasma GH level in a single blood sample taken 25 to 30 minutes from the start of a short period of intensive exercise. The results in that report were largely based on experiments conducted on healthy normal individuals, most of whom were postpubertal. Though information about $\mathrm{GH}$ function is of considerable value in adults suspected of hypopituitarism, the greatest application of such a test will be in the investigation of small stature in children. As the test is now being adopted in other centres (Hall, 1972; Jacobs, 1972), it seems advisable to draw attention to its limitations in its present form, and to stress that it is only a screening procedure. This report describes the results of the use of this test in children and young adults of short stature.

\section{Subjects and methods}

Fifty-nine children ( 17 girls and 42 boys) with short stature ( $<3$ rd centile for height) were studied. Most of these were referred for investigation of the shortness of stature, but a few had, in addition, delayed puberty or other features possibly attributable to pituitary insufficiency.

A single venous blood sample was taken 25 to 30 minutes after a short period of intensive exercise. In children sufficiently old and tall, this exercise was performed on a bicycle ergometer, and usually required 5 to 10 minutes hard pedalling. In small children the exercise could take other suitable forms such as running on the flat, up and down stairs, or skipping. The exercise was of sufficient intensity to render the subject breathless and fatigued, but not exhausted. The procedure was usually undertaken during the course of an outpatient visit. This could be at any time of day and the test did not involve fasting, restriction of preceding activity, or other special preparation. Plasma GH levels were measured by a double antibody radioimmunoassay (Buckler, 1970), and values are reported in $\mu U$ of the 1st International Reference Preparation of human growth hormone.

\section{Results}

Table I gives the results. A plasma GH level of $10 \mu \mathrm{U} / \mathrm{ml}$ or above is generally considered to indicate responsiveness. By this criterion, 44 of the 59 children were shown by this exercise test to be capable of releasing $\mathrm{GH}$.

TABLE I

Plasma GH levels after exercise in children of short stature

\begin{tabular}{|c|c|c|c|c|}
\hline \multirow{3}{*}{ Age (yr) } & \multicolumn{4}{|c|}{ No. of children } \\
\hline & \multirow{2}{*}{ Total } & \multicolumn{3}{|c|}{ Plasma $\mathrm{GH}$ levels $(\mu \mathrm{U} / \mathrm{ml})$ after exercise } \\
\hline & & $<10$ & $10-20$ & $>20$ \\
\hline $\begin{array}{c}\text { Girls } \\
<10 \\
10-15 \\
15-20 \\
\text { Total } \\
\text { Boys } \\
<10 \\
10-15 \\
15-20 \\
\text { Total }\end{array}$ & $\begin{array}{r}4 \\
11 \\
2 \\
17 \\
13 \\
18 \\
11 \\
42\end{array}$ & $\begin{array}{r}0 \\
3 \\
0 \\
3 \\
6 \\
3 \\
3 \\
12\end{array}$ & $\begin{array}{l}2 \\
3 \\
1 \\
6 \\
4 \\
3 \\
1 \\
8\end{array}$ & $\begin{array}{r}2 \\
5 \\
1 \\
8 \\
3 \\
12 \\
7 \\
22\end{array}$ \\
\hline $\begin{array}{l}\text { Total } \\
\text { (Girls and boys) }\end{array}$ & 59 & 15 & 14 & 30 \\
\hline
\end{tabular}


TABLE II

Analysis of children failing to show raised plasma GH levels after exercise

\begin{tabular}{l|l|l|l|}
\hline & No. of children \\
\hline GH deficiency proved by other tests of GH release & 5 \\
Normal GH function indicated by other tests of GH release & 3 \\
Normal GH function indicated by clinical criteria & 2 \\
Children undergoing further investigation & 5 \\
\hline \multicolumn{1}{c|}{ Total } & 15 & \\
\hline
\end{tabular}

Analysis of the 15 children whose plasma GH levels did not exceed $10 \mu \mathrm{U} / \mathrm{ml}$ is shown in Table II. 5 were subsequently considered on the basis of other more complex tests of $\mathrm{GH}$ release (insulin hypoglycaemia or Bovril stimulation) to be $\mathrm{GH}$ deficient. Of the remaining 10 children, only 3 were investigated by other stimulatory tests and shown to be capable of normal GH release. 1 of these, a 13-year-old boy who failed to show a GH response to exercise, also failed to produce raised $\mathrm{GH}$ levels after insulin hypoglycaemia. He had, however, a high fasting plasma $\mathrm{GH}$ value before insulin and was therefore concluded not to be $\mathrm{GH}$ deficient. 2 other children were considered not to be $\mathrm{GH}$ deficient in the light of fuller clinical assessment and not to warrant further GH studies.

The remaining 5 nonresponders have not yet undergone further $\mathrm{GH}$ studies, but are being reviewed in the light of their subsequent clinical course.

\section{Discussion}

This method of assessing ability to release $\mathrm{GH}$ is simple, acceptable, and convenient. It is, therefore, reasonable to use it in circumstances when fuller $\mathrm{GH}$ studies might not be so readily undertaken, and its main value is in avoiding unnecessary investigation in those children who show a positive response. A negative response, however, does not necessarily indicate $\mathrm{GH}$ deficiency.

About $75 \%$ of the children in this series referred because of small stature have been shown by this test not to be GH deficient and have therefore been prevented from more unpleasant alternative procedures and, frequently, the need of hospital admission. The previous report gave a value of $89 \%$ for the $\mathrm{GH}$ response to exercise in a group of 65 healthy subjects of normal stature who were mainly adults (Buckler, 1972). That study also showed that raised plasma GH levels are seldom found in blood samples taken randomly not after exercise.

The number of nonresponders depends to some extent on selection of cases. The $25 \%$ in the present series who failed to respond included some who were truly GH deficient, but many of the others subsequently proved to have given false negative results. However, these children have not suffered much discomfort as the result of this screening procedure.

There are many possible explanations for false negative responses, including incorrect timing of blood sampling, inadequacy of the exercise stimulus (particularly in the younger patients), and refractoriness after previous $\mathrm{GH}$ release. Some of these possibilities could only be avoided by measures which would render the test less convenient and less advantageous. It may be, however, as Okada et al. (1972) have recently suggested, that some children who have constitutional short stature may show a poor GH response to normal physiological stimuli such as exercise, even though it can be shown that they are capable of releasing GH to other unphysiological stresses.

\section{Summary}

Exercise has been used as a simple screening procedure for showing ability to release growth hormone in 59 children investigated for short stature. 44 were considered as the result of this test to have normal GH output; and of the 15 nonresponders, 5 have subsequently been proved to be $\mathrm{GH}$ deficient, and 5 were considered to have given false negative results. The remaining 5 children are undergoing further investigation.

It is concluded that a positive $\mathrm{GH}$ response to exercise is meaningful, but a negative response does not necessarily indicate $\mathrm{GH}$ deficiency.

\section{REFERENCES}

Buckler, J. M. H. (1970). Spontaneous variations in serum growth hormone levels. Acta Endocrinologica, 65, 342.

Buckler, J. M. H. (1972). Exercise as a screening test for growth hormone release. Acta Endocrinologica, 69, 219.

Hall, R. (1972). Diagnosis and management of hypopituitarism. Fournal of the Royal College of Physicians of London, 7, 19.

Jacobs, H. S. (1972). The clinical application of the measurement of human growth hormone. fournal of Endocrinology, 54, XXVI. 
Okada, Y., Hikita, T., Ishitobi, K., Wada, M., Santo, Y., and Harada, Y. (1972). Human growth hormone secretion after exercise and oral glucose administration in patients with short stature. Fournal of Clinical Endocrinology and Metabolism, 34, 1055.

J. M. H. BUCKLER

Department of Paediatrics and Child Health, University of Leeds, 27 Blundell Street, Leeds LS1 $3 E T$.

\section{Pica with rapid improvement after dietary zinc supplementation}

Recent evidence, derived primarily from measurements of hair zinc levels, has indicated that body zinc stores may be relatively low in infants and children less than 4 years of age in the United States (Hambidge et al., 1972). Moreover, the correlation observed between low hair zinc levels (70 p.p.m. or less), poor appetite, and low growth centiles suggested the occurrence of symptomatic zinc deficiency in some otherwise normal children. In the Middle East a high incidence of pica, manifested by geophagia, has been reported to occur in male adolescents who have evidence of severe symptomatic zinc deficiency (Prasad, Halsted, and Nadimi, 1961). It is not certain whether this geophagia was an aetiological factor contributing to the zinc deficiency, or if it was a feature attributable to a preceding deficiency of this essential micronutrient (Halsted et al., 1972). This report concerns an unusual case of pica which improved rapidly after starting dietary zinc supplementation.

\section{Case report}

A Caucasian female was the product of a normal pregnancy and delivery. Her birthweight was $3,300 \mathrm{~g}$ and length $51 \mathrm{~cm}$. Her mother's and father's heights were $163 \mathrm{~cm}$ and $185 \mathrm{~cm}$, respectively. Apart from her physical growth, her development was quite normal during infancy and she had no serious illnesses. Her weight centile, which was at the 50th until the age of 2 months, declined to the 3rd by 6 months of age, and subsequently remained at this centile (Fig.). Her height centile, which was on the 90th at 3 months of age, also declined in later infancy to the 25th by 11 months of age; and then, between 18 and 24 months, to the 10th centile. Her appetite was initially good and her early feeding habits were unremarkable. At 4 months of age she was taking $720 \mathrm{ml}$ milk formula and 3 meals of solid foods per day. However, from the age of 6 months her appetite was 'not so good', and at 18 months of age her mother reported a marked deterioration in appetite.

At the age of 18 months she began to eat metallic objects and, to a lesser extent, her own hair. These metallic objects, which she inserted into her mouth for extensive periods of time, included, for example, keys and aluminium foil. She was also observed to be gnawing frequently at the metal stripping on the edge of the carpets. Physical examination at the age of 24 months was unremarkable apart from her relatively poor growth and a marked silver discoloration of her teeth, the result of her unusual dietary habits. Her height was $82 \mathrm{~cm}$, weight $9.87 \mathrm{~kg}$, and haemoglobin $12.5 \mathrm{~g} / 100 \mathrm{ml}$. At this stage her hair was analysed (Hambidge, 1971) and the zinc concentration was 70 p.p.m. In view of this low level ( $>3$ SD below the mean for normal adults) (Hambidge et al., 1972) and her poor appetite and relatively poor growth, a therapeutic trial of dietary zinc supplementation was started. $5 \mathrm{ml}$ of a cherry-flavoured solution, containing $10 \mathrm{mg}$ zinc sulphate $\left(\mathrm{ZnSO}_{4} \times 7 \mathrm{H}_{2} \mathrm{O}\right.$

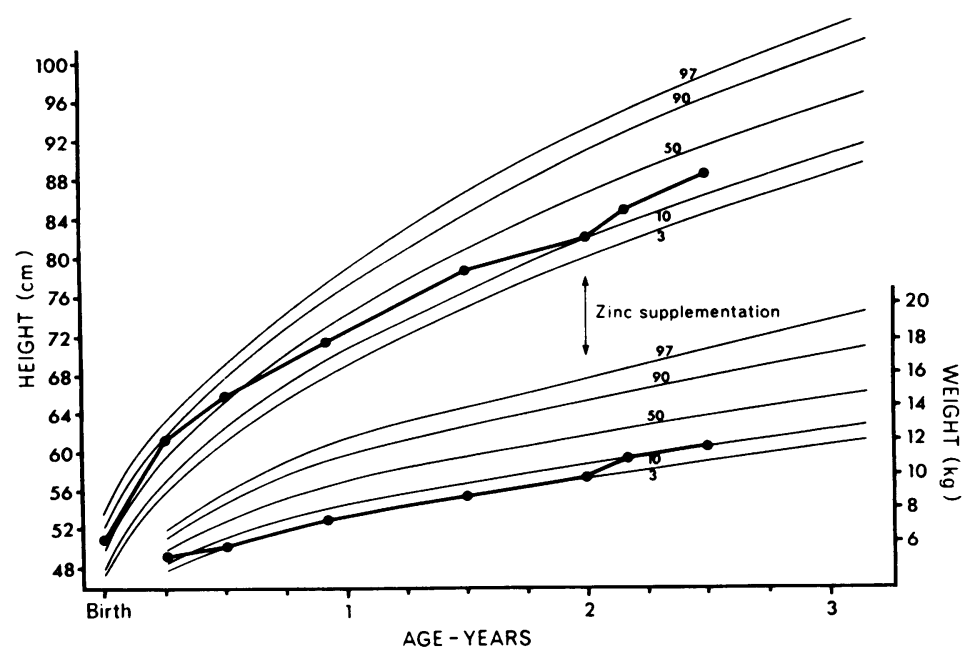

FIG.-Growth centiles before and after zinc supplementation. Centiles based on Harvard School of Public Health and Iowa Child Welfare Research Station data. 